Отримано: 4 грудня 2019 року

Прорецензовано: 9 грудня 2019 року

Прийнято до друку: 11 грудня 2019 року

e-mail: esps2015@gmail.com

DOI: $10.25264 / 2519-2558-2019-8(76)-131-136$
Ivantsova Oksana. The use of intensive technologies in english language learning process. Наукові записки Національного університету "Острозька академія»: серія "Філологія». Острог: Вид-во НаУОА, 2019. Вип. 8(76), грудень. С. 131-136.

Oksana Ivantsova,

УДК: 37:004.77

Ph.D. in Pedagogy,

\title{
THE USE OF INTENSIVE TECHNOLOGIES IN ENGLISH LANGUAGE LEARNING PROCESS
}

Along with technological advances, related learning technologies have also evolved, from simple forms of material distribution to more complex tools for communication, knowledge sharing, or forums. This rapid shifting of learning technologies raises the question of whether postsecondary education institutions are focused on keeping up with the changes rather than examining them for best practices and investigating the affect of these changes on instructors and learners.

Military education is a complex field subject to multiple pressures and competing agendas. One-size-fits-all recommendations are thus unlikely to satisfy anyone. However, a number of points are worth stressing. At a time when armed forces insist that uncertainty is a dominating feature of future operations, education - in the truest sense of the word-has never been more important for modern militaries than it is today. As such, debate about how best to deliver that education is healthy and beneficial, and all of those involved in professional military education ought to be proactively seeking opportunities for improvement and, if necessary, change.

The chances of getting in high quality educators who can offer constructive but critical new viewpoints is thus vastly increased by looking to the civilian sector, and by constituting faculties overwhelmingly from people who have dedicated their careers to teaching and research.

If modern militaries do value the educational outcomes their leaders espouse, what is necessary is greater investment in officers' development in a holistic sense, and greater trust that their students will engage with and benefit from education outside of a purely military curriculum. Opportunities for such education could be provided at higher education establishments, through online learning, blended learning or a combination of the above.

Two of the most important roles of education are to help students learn how to think, not what to think, and appreciate that learning is a lifetime activity.

Key words: learning technologies, dynamic processes, intensive training, military education, intensification.

Іванцова Оксана Петрівна,

кандидат педагогічних наук,

Житомирський військовий інститут ім. С. П. Корольова

\section{ВИКОРИСТАННЯ ІНТЕНСИВНИХ ТЕХНОЛОГІЙ У ПРОЦЕСІ ВИВЧЕННЯ АНГЛІЙСЬКОЇ МОВИ}

Поряд із технологічним прогресом розвинулися також технології навчання, від простих форм розповсюдження матеріалів до складніших засобів спілкування, обміну знаннями або форумів.

На сьогоднішній день необхідні більші інвестииї для підготовки майбутніх офімерів у иілісному розумінні та більща довіра, щз курсанти будуть залучатися до різноманітних освітніх діяльностей та отримувати додаткові уміння та навички за межами суто військової програми. Можливості такої освіти можуть бути надані у вищих навчальних закладах через онлайн-навчання, змімане навчання або комбінацію вищезазначеного.

Дві найважливімі ролі сучасної освіти - допомогти курсантам навчитися думати і розуміти, щуо навчання є життєво важливою діяльністю та такою, щзо відбувається протягом усього життя.

Ключові слова: інтенсифікація, онлайн навчання, дистаниійне навчання, технологї.

In the context of reforming the Armed Forces of Ukraine, there is an urgent need to review the approaches to determining the level of education and qualification of specialists for the organization of the educational process in educational institutions. Military education in the current situation requires the intensification of the educational process by introducing new learning technologies and methods of teaching.

An important component of Ukraine's foreign policy is a further deep military cooperation with international organizations, including the United Nations (UN), European Union (EU) and the North Atlantic Treaty Organization (NATO), where English is used as the main working language. In this context, the role of comprehensive language training of Ukrainian soldiers and their knowledge of military and business English, which is one of the main priorities in achieving interoperability of the parts and the Armed Forces of Ukraine during multinational exercises, peacekeeping, counter-terrorism and search and rescue operations under the auspices of international organizations, increases.

Improving the quality of training in high-tech professions involves mastering at least one foreign language. Learning English by the officers of the Armed Forces of Ukraine is aimed at each of them achieving a certain standardized language level according to the concept of language training of the personnel of the Armed Forces of Ukraine.

Dynamic processes occurring in the area of military activity, puts into first place the time factor that is needed for training to a specific educational qualification level and, the cost factor of specialist preparation, namely the effectiveness of cadet training.

The rapid growth of scientific information that has to be learned at different levels is one of the universally recognized scientific and technical features of social progress of the second half of the twentieth century. Nowadays it is known, that the quantity of world information doubles every 10-15 years. Scientists stress the fact that every minute about 2 thousand pages of scientific text is published in the world, annually about 7 billion pages of printed text are issued; a scientist must spend about 17 years of life 
mastering the scientific literature published per year. Moreover, in recent years we have moved from a shortage of information to its saturation. According to Eric Schmidt, every two days mankind creates as much information as was produced from the beginning of our civilization until 2013. It's about five exabytes of information per day. Today we need help in navigating to find the information that we seek.

Based on the foregoing, we can identify the following contradictions in the educational process:

1. The contradictions between the new needs and aspirations of the individual with level of the tools' mastery necessary to meet them.

2. The contradictions between the new cognitive goals, objectives and available means of action, and new situations and previous experience of the individual, and between established generalizations and new facts.

3. The contradiction between the daily intake of large amounts of information and familiar brain ability to perceive and remember information, imperfections of psychophysical development of a person.

4. The contradiction between usual workload, and training in conditions of high information and psychological stress with a deficit of study time.

The purpose of learning a foreign language in high school at the present stage is the mastery by the cadets of the communicative competences that will implement their knowledge and, skills for solving specific communication problems in real- life situations. Foreign language serves as a means of communication, dialogue with other nations and is a vital necessity. Cadets should be trained using modern, authentic educational materials for the use of foreign languages in later life and career. The purpose of teaching is to study the lexical, grammatical, morphological and stylistic fundamentals of the English language together with the achievements of the cadets' abilities to perform professional-oriented speech activity in the four main activities - Listening, Speaking, Reading and Writing. The planned outcome study: 2800-3400 lexical units of combined every day and military English; grammar rules to the extent necessary for communication, reading and writing in a foreign language; and the rules of military literature translation. To form general (professional, military, professional, special, etc.) competencies while studying to gain such competences, as follows:

Written communication:

- correspondence;

- resume writing.

Oral communication:

- participation in the discussion;

- rules of greetings and polite conversation;

- sharing information over the phone;

- exchange of views;

Social and cultural competence:

- work in a multicultural environment.

Among the topical issues is language training for professionals of the higher military school view the revision of educational programs towards dynamic compression for intensifying the language training of cadets; bringing the learning content according to the military experts' experience in combat and in the operational training of their troops, their use in peacekeeping missions, local conflicts and wars; searching for new teaching methods to improve the speed and quality of memorizing information; refurbishment of educational facilities; increasing the resources for motivational training activities. The intensification of the educational process, with its heavy load of information and psycho-physiological tensions, refers to improving the efficiency of learning, not simply by increasing labor costs, time, teachers and cadets, and financial resources, which is typical for extensive development, but primarily due to their more efficient use and creation of favorable conditions and the perception of educational material. It provides a full and reasonable use of the achievements of pedagogy and psychology, sociology and other sciences. The aim of intensifying training in higher military school - through the integrated use of the most effective forms, methods and means of teaching and the organization of close cooperation between them, is to ensure that it better meets modern requirements to practise military training to highly qualified specialists.

Intensive training is based on the consistent use of various learning activities that provide a gradual increase in levels of assimilation of educational information from the level of "readiness" through to the levels of "recognition", "reproduction", "application" to "creativity". The main ones are: the formation of study groups on the results of test performance, rapid reading, note-taking at various levels of communication, role communicative games, competitions and collective creativity. These techniques of intensive training in humanities have a continuity of traditional methods, as for all stages of learning using conventional teaching materials for traditional courses.

Unlike traditional teaching, intensive training includes a number of new types of training activities aimed at self-improvement and the harmonious development of the cadet's personality. Independent work requires the ability to overcome physiological barriers using techniques of psycho-selfregulation, and include such kinds of educational activities as dynamic reading, rational methods of working with texts, participating in role-playing games, competitions and more.

In the context of intensification of the learning process the overcoming of barriers happens and it needs a special psychophysiological situation that mobilizes the body to overcome them. This creates information "overload" in conjunction with simultaneous psychological compensation, in game form, in a suggestive emotional "relief." Thus, the most informative stimulation allows the subconscious to download large amounts of information.

Our aim is to search known tends of intensifying education at high information and psychological tension. While analyzing the possibilities of increasing the intensity of perception of new material we cannot pay attention to distance education, blended learning, open learning and boundary-crossing learning.

The results of the literature review are organized to first present emerging approaches, second to consider learners and educators, and third and the fourth to focus on education in the military.

Changes to Distance Education with the Emergence of Technology

With the emergence of learning technologies, traditional paper-based courses were either supplemented by or evolved into other forms of learning defined as e-learning, online, or web-based learning. E-learning refers to the use of multimedia technologies and the Internet to improve the quality of learning by facilitating access to resources and services as well as exchanges and remote 
collaboration $[3,5]$. E-learning has resulted in more people accessing higher education and has subsequently influenced societies around the world [10, p.8]. The discussion of specific Internet-based devices and their possibility to offer learning situations virtually anywhere has shifted to exploring the emerging web technologies that are used on such devices [1, 5]. Abrami, Bernard, Bures, Borokhovski and Tamim (2011) argue that as a result of the emerging technologies, "distance education and online learning have evolved beyond simple comparisons with classroom instruction" [2, p. 82-103]. They contend that emerging technologies have the power to create interactions that are "guided, focused, and purposeful" and to enable learners to interact via technology in more complex ways through different forms of communication that use images, statements, or presentations, to name a few. Kearney, Schuck, Burden, and Aubusson (2012) have suggested that mobile learning can be viewed from a sociocultural perspective in which learning is affected and modified by the tools used for learning, which in turn influence the ways the tools are used. Evidence of this concept in practice can be seen in the boom in social networking that has spanned the globe. Research now links the use of social networking as a key element in knowledge construction [8, p.1-17].

\section{Blended Learning}

In line with the theory of social networking as a form of knowledge construction and the need for interaction among learners, are the concepts of blended learning or hybrid learning, which refer to learning that combines face-to-face classroom interaction with distance learning techniques to disseminate instructional materials and information. Blended learning can be used to provide a balance between virtual learning components with face-to-face interaction, thus increasing the likelihood for meaningful learning. However, it is important to ensure that pedagogical underpinnings (i.e. learning theory, instructional design, and the needs of the learners, etc.) are not overlooked in a blended learning environment $[6,5]$.

\section{Open Learning}

Another trend that emerged in 2008 is that of Massively Open Online Courses (MOOCs) [11, 7]. Originally based on connectivism and networking (Daniel, 2012), MOOCs are primarily characterized by the following criteria: they are delivered online, offer large enrolment, are open for participation with little to no cost to the students, and follow a course format with learning goals specific to an area of $[3,5]$. While sharing vast amounts of information and having a large student base is appealing for higher education institutions, MOOC learner persistence is of great concern. Researchers at the University of Edinburgh found that nearly $45 \%$ of learners who enrolled in MOOCs never became active learners in the online setting, with even fewer learners progressing through the course to obtain a statement of achievement indicating their learning [12, 5].

\section{Boundary-crossing learning}

In theorizing boundaries and learning, the research focuses on empowering participants to undertake boundary-crossing learning, which means purposeful and negotiated learning with culturally diverse people. Boundary-crossing may delineate organisations, locations and social groups; their exact natures are established in discussions between "boundary brokers" [5, p.10]. Boundaries mark distinctions of characteristics such as political control, competence and behaviour. Boundary objects are artefacts of sufficient plasticity that they can be interpreted by multiple groups whilst retaining common identity for those groups [9, p.25]. Boundary objects ought to assist with collaborative work, whilst enhancing the contributions of diverse knowledge and meaning [4, p.87].

So, time dictates its own requirements and current situation of foreign language learning in higher military educational institutions has changed significantly. Thanks to the spirit of the times and changes in general in the world and in the minds of people the knowledge of foreign languages is obvious. Today it is important to prepare not only the specialist, but also a professional, when not military strength will be a decisive factor in the victory but the professionalism of military personnel. The results of the world, local wars, armed conflicts, major strategic operations, battles show that their success depends strongly on training, moral and fighting qualities of officers, their ability to identify and plan major measures to improve the combat readiness of troops (forces) and ability to implement them effectively into practice. Finally, education of our most innovative leaders is important both for executing the current national security strategy today, and for preparing future generations to adapt quickly and effectively so we won't be caught in a catch-up mode.

\section{References:}

1. Abik, M., Ajhoun, R., \& Ensias, L. (2012). Impact of technological advancement on pedagogy. Turkish Online Journal of Distance Education, 13(1), 224-237.

2. Abrami, P. C., Bernard, R. M., Bures, E. M., Borokhovski, E., \& Tamim, R. M. (2011). Interaction in distance education and online learning: using evidence and theory to improve practice. Journal of Computing in Higher Education, 23, 82-103.

3. Educause (2013). 7 things you should know about MOOCs II. Educause learning initiative. Retrieved from http://www.educause.edu/ library/resources/7-things-youshould-know-about-moocs-ii.

4. Fominykh, M., Prasolova-Førland, E., Divitini, M., \& Petersen, S. A. (2016). Boundary objects in collaborative work and learning. Information Systems Frontiers, 18(1), 85-102.

5. Grazia Scoppio Mapping Trends in Pedagogical Approaches and Learning Technologies: Perspectives from the Canadian, International, and Military Education Contexts/ Canadian Journal of Higher Education Revue canadienne d'enseignement supérieur Volume 46, No. 2, 2016, pages $127-147$.

6. Hiltz, S. R., \& Turoff, M. (2005). Education goes digital: The evolution of online learning and the revolution in higher education. Communications of the ACM, 48(10), 59-64.

7. Howard, K. (2014). Massive open online courses (MOOCs): Implications and opportunities for the community college system in New Brunswick. Post-Secondary Education, Training and Labour, Government of New Brunswick.

8. Kearney, M., Schuck, S., Burden, K., \& Aubusson, P. (2012). Viewing mobile learning from a pedagogical perspective. Research in Learning Technology, 20, 1-17.

9. Kimble, C., Grenier, C., \& Goglio-Primard, K. (2010). Innovation and knowledge sharing across professional boundaries: Political interplay between boundary objects and brokers.Maaninen-Olsson, E., \& Carlsson, S. (2006). Knowledge Integration and the Meaning of Boundary Activities. In OLKC 2006 Conference at the University of Warwick (pp. 1-28). Warwick.

10. Means, B., \& Roschelle, J. (2010). Technology and learning: An overview of technology and learning. International Encyclopedia of Education, 1-10.

11. Skiba, D. J. (2013). On the horizon: The year of the MOOCs. Nursing Education Perspectives, 34(2), 136-137.

12. Woodgate, A., Macleod, H., Scott, A. M., \& Haywood, J. (2015). Differences in online study behaviour between sub-populations of MOOC learners. Educación XX1, 18(2), 147-163. 
Отримано: 2 грудня 2019 року

Прорецензовано: 9 грудня 2019 року

Прийнято до друку: 11 грудня 2019 року

e-mail: happysteinbock999@gmail.com

DOI: $10.25264 / 2519-2558-2019-8(76)-136-136$
Колмикова О. О. Мовленнєва толерантність як необхідна вимога для успішної праці в інтернаціональних екіпажах торгівельного флоту. Наукові записки Національного університету «Острозька академія»: серія «Філологія». Острог: Вид-во НаУОА, 2019. Вип. 8(76), грудень. С. 136-136.

Колмикова Олена Олександрівна,

УДК: 378 [658, 612:001]

кандидат філологічних наук

Дунайський інститут Національного університету «Одеська морська академія»

\section{МОВЛЕННЕВА ТОЛЕРАНТНІСТЬ ЯК НЕОБХІДНА ВИМОГА ДЛЯ УСПНШНОӤ ПРАЦІ В ІНТЕРНАЦІОНАЛЬНИХ ЕКІПАЖАХ ТОРГІВЕЛЬНОГО ФЛОТУ}

У статті розглядаються поняття «толерантність» та «мовленнєва толерантність», обтрунтовується необхідність формування мовленнєвої толерантності у майбутніх моряків торгівельного флоту, які планують працювати в інтернаціональних екіпажах, зроблено акцент на важливості виховання у курсантів морських академій поваги до різних національностей, культур та релігій, приводяться приклади вправ, метою яких є забезпечення злагодженої роботи в міжнаціональних командах (складання діалогів, полілогів, вивчення мови жестів різних культур), аналізуються причини непорозуміння між членами інтернаціональних екіпажів торгівельних суден, з'ясовується, що найчастіше аварії на морі зумовлені саме недостатнім володінням англійською мовою, виділяються переваги та недоліки змішаних екіпажів.

Ключові слова: мовленнєва толерантність, торгівельний флот, іншомовна комунікація, інтернаціональний екіпаж, майбутні моряки.

\section{Olena Kolmykova,}

PhD in Linguisticts, Associate Professor of Department of Humanities,

Danube Institute of the National University "Odessa Maritime Academy"

\section{SPEECH TOLERANCE AS AN IMPORTANT DEMAND FOR SUCCESSFUL WORK IN INTERNATIONAL CREWS OF MERCHANT FLEET}

The problem of speech tolerance is of vital importance for successful and safe work on board merchant ships in international crews as it enables to establish communication and mutual understanding between the seafarers. Nowadays when the number of seafarers from the major ship building countries (the USA, Japan, EU) decreased, the crewing agencies have to hire sailors from different countries. It has its advantages and drawbacks, as mixed crews, comprising representatives of different nationalities, cultures and religions, speak English as the language of international communication. At the same time, English is the foreign language for most of them. Analyses of the accidents and incidents at sea have shown that in most cases they were caused by the so-called "human factor." Improper level of English knowledge leads to misunderstanding and results in serious professional problems. This is why it is so important to train cadets of Maritime Academies to speak, write and understand fluent English speech in the process of verbal communication.

When working in the international crews, the seafarers must not only be able to communicate in English, but they also must be familiar with the so-called "communicative norm" of their co-workers. It means that sailors have to know the peculiarities of the culture, religion and even food traditions of the members of the crew. For this purpose, when training cadets in Maritime Academies it is reasonable to work out dialogues and polylogues imitating communication of representatives of different countries and religions. Besides, it is important to teach them the gesture language used in various countries to ease the communication between the members of the crew and to avoid misunderstanding between them.

Key words: speech tolerance, merchant vessels, foreign language communication, international crew, future seafarers.

Постановка проблеми. Зменшення кількості моряків з основних країн-власників суден, таких як США, Японія та країни $€ \mathrm{C}$, змусили керівництво морської галузі приймати на роботу спеціалістів з різних країн світу. Дві третини світових торгівельних суден наймають на роботу представників різних культур, які розмовляють різними мовами. Це означає, що моряки повинні бути не лише технічними фахівцями, але й добре володіти англійською мовою, вміти адаптуватися серед іноземців, та навчитись злагоджено працювати в команді.

Інтеграційні процеси і глобалізація в морській галузі вимагає від моряків-представників різних культур вміння спілкуватися, співпрацювати, находити «спільну мову» для вирішення складних професійних питань, ставитись з розумінням та повагою до розбіжностей в поглядах та звичках. Кожна людина - це особистість, тому досягти почуття товариськості складно навіть серед співвітчизників, не кажучи вже про представників різних країн, які не лише мають розбіжності в картині світу, але й навіть розмовляють іншими мовами.

Створення міжнаціональних екіпажів викликає певні труднощі, запобігти яким дуже складно. Непорозуміння, обмеження спілкування внаслідок недостатнього рівня володіння англійською мовою, дискримінація через расу, культуру, національність чи релігію можуть призвести до нещасних випадків та аварій. Саме тому виникає необхідність в вихованні в моряків толерантності к представникам інших країн.

Під «толерантністю» (від латинського tolero - нести, переносити, витримувати, терпіти) розуміють терпіння, терплячість й витривалість. Резолюцією 5.61 Генеральної конференції ЮНЕСКО від 16 листопада 1995 року затверджено Декларацію принципів толерантності, в якій поняттю «толерантність» дається таке визначення як повага, прийняття і правильне розуміння багатого різноманіття культур нашого світу, наших форм самовираження і способів прояви людської індивідуальності [7].

Проблема толерантності в різних сферах діяльності людини визиває жвавий інтерес дослідників. Цією проблемою займалися Ф.Бацевич, Т.Білоус, А.Васильєв, В.Гольдін, Е.Ларіна, Е.Морозов, І.Стернін, Г.Яворська та ін. Проте майже поза увагою науковців залишається проблема мовленнєвою толерантності в інтернаціональних екіпажах торгівельного флоту. 
Актуальність цієї статті обумовлена необхідністю дослідити основні шляхи формування мовленнєвої толерантності моряків, вимушених працювати в інтернаціональних екіпажах серед представників інших країн, культур та національностей.

Викладення основного матеріалу. Як відомо, однією з першорядних умов сучасного суспільства $є$ взаєморозуміння індивідуумів в процесі мовленнєвої комунікації. Найбільш важливою ця проблема стає в умовах обмеженого простору корабля, де представники змішаних команд не лише говорять різними мовами, але й належать до різних культур та релігійних співтовариств. Слід зазначити, що англійська мова, як мова міжнаціонального спілкування, не $є$ рідною для більшості 3 них. Звісно, це викликає певні труднощі в професійному спілкуванні на торгівельних судах. Аналіз аварій на морі свідчить про те, що причиною більшості з них є так званий «людський фактор». Саме тому так важливо забезпечити флот спеціалістами, які б вільно володіли англійською мовою не лише для виконання професійних обов'язків, але й для порозуміння між співробітниками-членами екіпажу.

Оскільки саме англійська мова є мовою міжнаціонального спілкування, аби досягти успішної комунікації, фахівцям потрібно володіти іншомовною міжкультурною компетенцією в галузі професійної комунікації, під якою розуміється сукупність знань о рідній та іншомовних культурах, вмінь та навичок розуміння та адекватного використовування в мовленні міжкультурної лексики, застосовування знаннь про культуру носіїв мови в професійно спрямованих ситуаціях іншомовного спілкування і здатності брати участь в професійній міжкультурній взаємодії [5].

Процеси взаємодії і комунікації висувають на перший план проблеми подолання мовленнєвих бар'єрів. Для того, щоб зробити комунікативний процес успішним, необхідно не лише вміти розмовляти однією мовою, але й дотримуватися спільної комунікативної норми. Саме за цієї умови учасники комунікативного процесу можуть бути здатні побудувати єдиний комунікативний простір. Комунікативна норма - це складне поняття, до якого входять не лише мовленнєві форми, але й екстралінгвістичні елементи, такі як уявлення про культуру та традиції учасників комунікації, національний менталітет комунікації і толерантність до мовленнєвих і культурних відмінностей.

В сучасному світі екіпажі морських суден - це поєднання культур. Саме тому непорозуміння серед членів екіпажу можуть виникати не лише через мовленнєвий бар'єр, але й через недостатні знання про іноземні культури. У процесі комунікації у свідомості кожного з учасників спілкування присутня модель навколишнього світу, модель співрозмовника, модель структури діалогу, модель себе як мовленнєвої особистості, модель мови спілкування.

Як відомо, світова культура складається з культури Сходу та Заходу. Представникам різних культур інколи дуже складно зрозуміти одне одного внаслідок об'єктивних причин. Р. Льюіс створив таблицю, яка добре ілюструє розбіжності між двома культурами [14].

Приведемо таблицю в перекладі на українську мову.

\begin{tabular}{|c|c|}
\hline Західні культурні погляди & Східні культурні погляди \\
\hline \multicolumn{2}{|c|}{ Цінності } \\
\hline $\begin{array}{l}\text { Демократія } \\
\text { Рівність } \\
\text { Самовизначення } \\
\text { Індивідуалізм } \\
\text { Права людини } \\
\text { Рівність для жінок } \\
\text { Соціальна мобільність } \\
\text { Статус через досягнення } \\
\text { Факти і цифри } \\
\text { Соціальна справедливість } \\
\text { Нові рішення } \\
\text { Рішучість } \\
\text { Лінійний час } \\
\text { Орієнтація на результат }\end{array}$ & $\begin{array}{l}\text { Iєрархія } \\
\text { Нерівність } \\
\text { Фаталізм } \\
\text { Колективізм } \\
\text { Прийняття статусу } \\
\text { Домінування чоловіків } \\
\text { Встановлення соціального класу } \\
\text { Статус завдяки багатству } \\
\text { Відносини } \\
\text { Силові структури } \\
\text { Хороші прецеденти } \\
\text { Мудрість } \\
\text { Циклічний час } \\
\text { Орієнтація на гармонію } \\
\end{array}$ \\
\hline
\end{tabular}

\begin{tabular}{|c|c|}
\hline Західні культурні погляди & Східні культурні погляди \\
\hline \multicolumn{2}{|c|}{ Стиль спілкування } \\
\hline $\begin{array}{l}\text { Прямий } \\
\text { Різкий } \\
\text { Ввічливий } \\
\text { Говіркий } \\
\text { Екстраверт } \\
\text { Переконливий } \\
\text { Неуважний } \\
\text { Дивлячись прямо в очі } \\
\text { Лінійно активний } \\
\text { Однозначний } \\
\text { Рішучій } \\
\text { Вирішення проблем } \\
\text { Перебиває } \\
\text { Слухає неуважно } \\
\text { Діє швидко } \\
\text { Концентрується на владі }\end{array}$ & $\begin{array}{l}\text { Непрямий } \\
\text { Дипломатичний } \\
\text { Дуже ввічливий } \\
\text { Стриманий } \\
\text { Інтроверт } \\
\text { Рекомендуючий } \\
\text { Дуже уважний } \\
\text { Не дивлячись прямо в очі } \\
\text { Реакційний } \\
\text { Нечіткий } \\
\text { Обережний } \\
\text { Прийняття ситуації } \\
\text { Не перебиває } \\
\text { Слухає уважно } \\
\text { Розводить церемонії } \\
\text { Концентрується на узгодженому порядку денному }\end{array}$ \\
\hline
\end{tabular}




\begin{tabular}{|l|l|}
\hline \multicolumn{1}{|c|}{ Західні культурні погляди } & \multicolumn{1}{|c|}{ Східні культурні погляди } \\
\hline \multicolumn{1}{|c|}{\begin{tabular}{l} 
Стиль управління \\
\hline Індивідуум як одиниця
\end{tabular}} & $\begin{array}{l}\text { Компанія та суспільство як одиниця } \\
\text { Просування з віком та стажем } \\
\text { Вертикальні структури }\end{array}$ \\
$\begin{array}{l}\text { Просування за досягненнями } \\
\text { Горизонтальні та матричні структури } \\
\text { Орієнтація на прибуток } \\
\text { Контракти як обов'язкові } \\
\text { Рішення компетентних осіб } \\
\text { Спеціалізація } \\
\text { Професійна мобільність }\end{array}$ & $\begin{array}{l}\text { Пріоритет ринкової частки } \\
\text { Контракти як договірні } \\
\text { Рішення шляхом консенсусу } \\
\text { Ротація роботи } \\
\text { Фіксована вірність }\end{array}$ \\
\hline
\end{tabular}

Як бачимо з таблиці, розбіжностей в стилі спілкування, цінностях, структурі субординації у представників Сходу та Заходу забагато. Саме тому необхідною умовою успішної комунікації суб'єктів, що належать до різних культур, є мовленнєва толерантність.

Що ж таке мовленнєва толерантність? Єдиної відповіді на це питання не існує. Так, під мовленнєвою толерантністю можна розуміти терпимість і поблажливість до впровадження «чужорідної» мовленнєвої матерії (жаргонізмів, арготизмів, тощо) в нормативну систему мови (так, наприклад, англійська мова як засіб міжнаціонального спілкування пристосовується до нових умов комунікації і адаптується до різних зовнішніх впливів); пасивну адаптацію до мінливих умов комунікації; активний прояв толерантності до незвичних методів спілкування. Але, мабуть, найбільш точним буде визначення поняття мовленнєвої толерантності як терпимості до чужої культури і звичаїв.

Чи існують шляхи забезпечення мовленнєвої толерантності? Звісно, що так. В морських академія слід не лише навчати курсантів морської англійської мови, але й необхідно виховувати в них повагу до інших національностей, культур та релігій. Для досягнення цієї мети доцільно розробляти різноманітні програми навчання, мета яких полягає в ознайомленні з різними культурами і проведенні рольових ігор, які представляють найбільш типові бортові сценарії, беручи за основу діалоги і полілоги за участю кількох національностей в якості комунікантів. Крім того, необхідно вивчати мову жестів, що вживаються в різних країнах, так як один і той же жест в різних культурах може мати неоднакове значення. Майбутні моряки-члени інтернаціональних команд повинні чітко усвідомлювати, що їм доведеться протягом багатьох місяців працювати та жити в умовах обмеженого простору судна серед представників інших народів та культур, які можуть відрізнятися не лише мовою, яка є рідною для них, але й мати зовсім інші щоденні звички, улюблені страви, тощо. Разом 3 тим, міжнаціональний екіпаж має і певні переваги, серед яких є можливість розширити свою картину світу, вивчити іноземну мову, спробувати національні страви, навчитись чомусь новому.

Висновки. Змішаний екіпаж, не зважаючи на те, що він складається з представників різних культур, має бути згуртованим. Моряки, змушені находитись довгі місяці в достатньо стресових умовах обмеженого простору, повинні співпрацювати та добре розуміти одне одного, щоб уникнути аварійних ситуацій. Забезпечення мовленнєвої толерантності в міжнародних екіпажах суден сприятиме кооперації між членами команди. Саме тому вона $є$ необхідною умовою для забезпечення злагодженої роботи команди незалежно від національних, культурних чи релігійних відмінностей.

\section{Література:}

1. Бацевич Ф. Лінгвокультурні аспекти комунікативної толерантності. Соиіогуманітарні проблеми людини. 2010. № 5. С. 108-119.

2. Бех І. Д. Почуття цінності іншої людини як моральний пріоритет особистості. Початкова школа. 2001. № 12. С. 32 - 35.

3. Васильев А. Д. Об относительных преимуществах толерантности. Актуальные проблемы изучения языка и литературы: толерантность и интеграция. Абакан, 2004.

4. Морозов Е. А. К вопросу о статусе речевой толерантности в спорте. В мире науки и искусства: вопросы филологии, искусствоведения и культурологии: сб. ст. по матер. ХІ междунар. науч.-практ. конф. Часть І. Новосибирск: СибАК. 2012.

5. Погодина А. А. Толерантность: термин, позиция, смысл, программа. URL: http://his.1september.ru/2002/11/2.htm (дата звернення: 01.12.2019).

6. Походзей Г. В. Развитие иноязычной межкультурной компетенции курсантов речного училища в центре языкового обучения : дисс. ... кандидата педагогических наук : 13.00.02. Екатеринбург, 2013. 247 c. URL: http://www.dslib.net/teoria-vospitania/razvitieinojazychnoj-mezhkulturnoj-kompetencii-kursantov-rechnogo-uchiliwa-v-centre.html (дата звернення: 30.11.2019).

7. Резолюція 36/55 Генеральної Асамблеї ООН «Декларація про ліквідацію всіх форм нетерпимості та і дискримінації на основі релігії або переконань; Резолюція, Міжнародний документ. URL: http://www.zakon2.rada.gov.ua.

8. Сковородников А. П. К становлению системы лингвоэкологической терминологии. Речевое общение: специализированный вестник. 2000. Вып. 3(11). Красноярск. С. 70-78.

9. Філософський енциклопедичний словник / [голова редкол. В. І. Шинкарук]. К.: Абрис, 2002. С. 642.

10. Лісовий В. Толерантність. Філософський енциклопедичний словник / В. І. Шинкарук (голова редколегії) та ін. ; Л. В. Озадовська, Н. П. Поліщук (наукові редактори) ; І. О. Покаржевська (художнє оформлення). Київ: Абрис, 2002. С. 642.742 с.

11. Хомяков М. Б. Толерантность: парадоксальная ценность. Журнал соџиологии и сочиальной антропологии. 2003 . № 4. T. VI. № 4. C. $98-112$.

12. Шарифуллин Б. Я. Толерантность и объективность. Речевое общение: специализированный вестник. Вып. 8-9 (16-17). Красноярск, 1952. С. 118-121.

13. Яворська Г. Х., Ларіна Е. В., Мовна толерантність у контекстісоціально-гуманітраних наук (Частина I). Науковий вісник Міжнародного гуманітарного університету. Сер.: Філологія. 2016. № 20. Т. 1. С. 103-106. 2003 .

14. Lewis R. D. Cultural Orientation Affecting Leadership Styles. The Cultural Imperative. Boston: Nicholas Brealy/Intercultural Press,

15. Susetyo Didin Alfiani. Multinational and multicultural seafarers and MET students: a sociocultural study for improving maritime safety and the education of seafarers. World Maritime University Dissertations. 2010. 